Pak. j. sci. ind. res. Ser. A: phys. sci. 201457 (1) 40-46

\title{
Seasonal Variations in Dissolved Heavy Metals in Pompom River, Itakpe, Nigeria
}

\author{
Christiana Omono Matthews Amune* and Samuel Kakulu \\ Department of Chemistry, University of Abuja, Abuja, Nigeria
}

(received May 21, 2012; revised september 30, 2012; accepted October 23, 2012)

\begin{abstract}
Seasonal variations in dissolved heavy metals cadmium $(\mathrm{Cd})$, copper $(\mathrm{Cu})$, nickle $(\mathrm{Ni})$, lead $(\mathrm{Pb})$, and zinc $(\mathrm{Zn})$ in Pompom river, flowing across Itakpe iron mine, Nigeria, was studied using flame atomic absorption spectroscopy (FAAS). Precision for the determination of heavy metals in water ranged 3-16\% and recovery studies gave $79-104 \%$. The average concentrations in the dry and rainy seasons for heavy metals in Pompom river were $0.03 \pm 0.003,0.05 \pm 0.002,0.01 \pm 0.002,0.01 \pm 0.001$ and $0.04 \pm 0.002$ $\mathrm{mg} / \mathrm{L}$ for $\mathrm{Cd}, \mathrm{Cu}, \mathrm{Ni}, \mathrm{Pb}$ and $\mathrm{Zn}$, respectively. Seasonal variation showed metallic levels in water to be higher during the rainy season than dry season. $\mathrm{Cu}, \mathrm{Ni}, \mathrm{Pb}$ and $\mathrm{Zn}$ metallic levels of the studied metals were within the values of Federal Environmental Protection Agency (FEPA) of Nigeria and WHO permissible guidelines for drinking water.
\end{abstract}

Keywords: mining, seasonal variations, heavy metals, river, monitoring

\section{Introduction}

The existence of metals in aquatic environments has led to contamination of natural waters due to their hazardous effects. Sources of metals in waters can be natural or anthropogenic. Natural sources are weathering effects on rocks and minerals, while anthropogenic sources are associated with mining, agricultural applications, untreated industrial wastes, atmospheric sources etc., (Abolude et al., 2009; Papafilippaki et al., 2008; Marcovecchio et al., 2007; Laws, 2000). Worldwide industrial discharge is reported to be responsible for dumping 300-400 million tonnes of heavy metals and other wastes into water annually (Palaniappan et al., 2010). Such discharges have resulted into toxic substances released into the environment contributing to a variety of toxic effects on living aquatic organisms in food chain and degradation of water quality. Traichaiyaporn and Chitmanat (2008) reported that due to metal pollution in the upper Ping river, Thailand, death of fish and migration of some aquatic organisms occurred. Health effects in humans such as kidney dysfunction, cancer and sometimes death have been reported due to water pollution (Lawson, 2011).

Many developing regions of the world are facing unmonitored mining activities which have resulted in metal polluting the water ecosystems. Selenga river Basin in Mongolia mine vicinity for example, is reported to

*Author for correspondence;

E-mail: omonomathews@yahoo.com contribute $1 \%$ and $3 \%$ of the world flux of dissolved $\mathrm{Fe}$ and $\mathrm{Pb}$, respectively (Thorslund et al., 2012). Heavy metals are of particular interest considering their toxicity at low concentrations, synergistic effects, average long life, persistence, ability to bioaccumulate and potential adverse health effects to humans, animals, plants and ecosystems in general ( Traichaiyaporn and Chitmanat, 2008; Marcovecchio et al., 2007). In mining sites the potential to pollute the environment is enhanced by the high content of metals in mineral ore, and their proximity to streams. Acid mine drainage is reported to be responsible for the degradation of more than $12,000 \mathrm{~km}$ of streams in the Appalachaian region of the northeastern, USA (DeNicola and Stapleton, 2002). Heavy metal concentration in wells located near mining sites has been reported to contain levels that exceed drinking water criteria. Surface waters in the vicinity of abandoned mine sites also require monitoring. Studies of spoil heaps which polluted water flows in an abandoned mercury mine site in Asturias, in Spain reported acidic conditions and high As contents (Loredo et al., 2005).

Agricultural activities also release metals into water bodies which significantly affect the quality of water. The concentration of metals dissolved in water may give a misleading picture of the degree of contamination and hence under estimation of the total metal concentration in the water body (Palaniappan et al., 2010; Abolude et al., 2009; Laws, 2000). Thus heavy metal concentrations and flow data require strict 
monitoring to determine concentrations below healthrisk based guideline values.

The accurate determinations of heavy metals in aquatic environment are of ultimate importance for controlling their pollution. Numerous studies abound on the concentration levels of heavy metals in aquatic environments globally but a few has been carried out in water ecosystems of Nigeria. This work is an exploratory approach for baseline data for water quality through the determination of concentration of heavy metals in Pompom river flowing across Itakpe iron mine, Nigeria. The studies aims to determine the seasonal variation of $\mathrm{Cd}, \mathrm{Cu}, \mathrm{Mg}, \mathrm{Ni}, \mathrm{Pb}$ and $\mathrm{Zn}$ in the Pompom river and providing data on water quality assessment.

\section{Materials and Methods}

The study area is the Itakpe mining environment located in Okehi local government of Kogi State, Nigeria. The mine deposit is located within longitude $6^{\circ} 16^{\prime} \mathrm{E}$ and latitude $7^{\circ} 36^{\prime} \mathrm{N}$. The climate of the area is characterised by 6 months (May to October) of rainy season (RS) and 6 months (November to April) of dry season (DS). Agricultural practice in this area is at subsistence level with cultivation of food crops. River Pompom flows across the mining site. This river serves for irrigation, fishing, drinking, domestic and grazing purposes.

All the water samples were collected from the river Pompom between January, 2010 and December, 2010. A total of 150 water samples (25 samples per sampling location and 75 samples per season) were collected each in 4 litters plastic container and properly closed during each season from river Pompom at L4 (up stream), L3 (point of entry of industrial effluents) and L2 (downstream). The dry season (DS) samples were collected in January 2010, while the rainy season (RS) samples were collected in July 2010. Figure 1 shows map of Itakpe mining environment with the sampling points, while, Table 1 shows sample descriptions and locations.

Water samples were collected by immersion of the container below water level. The containers were completely filled with water and the water samples were not filtered prior to analysis. $1 \% \mathrm{HNO}_{3}$ solution was added to acidify the sample to a $\mathrm{pH}$ of $<2$ as preservative. The same treatment was given to the blank samples.

USEPA (2008) method was used to digest the water samples. $100 \mathrm{~mL}$ sample volume was transferred into a beaker and $6 \mathrm{~mL}$ of conc. $\mathrm{HNO}_{3}$ was added. The beaker was placed on a hot plate and the sample was evaporated to near dryness, making certain the sample did not boil. The beaker was cooled and another $6 \mathrm{~mL}$ of conc. $\mathrm{HNO}_{3}$ was added. The beaker was covered with a watch glass and returned to the hot plate. The temperature of the hot plate was increased for a gentle reflux. The sample was evaporated to near dryness and the beaker cooled, $5 \mathrm{~mL}$ of 1:1 $\mathrm{HCl}$ was added. The beaker was warmed and the sample $\mathrm{pH}$ adjusted to $\mathrm{pH} 4$ with $5 \mathrm{M} \mathrm{NaOH}$ solution. The sample was then transferred to a volumetric flask and the volume diluted to $25 \mathrm{~mL}$ with deionised water. The extract was analysed using AAS. The same procedure was carried out for blank and spiked samples.

Atomic absorption spectrophotometer (AAS) model 210VGP, Buck Scientific Incorporated USA was used for the determination of heavy metals. The wave lengths used for measurements were 326.1 for $\mathrm{Cd}, 324.7$ for $\mathrm{Cu}, 285.2$ for $\mathrm{Mg}, 341.5$ for $\mathrm{Ni}, 283.3$ for $\mathrm{Pb}$ and $213.9 \mathrm{~nm}$, for $\mathrm{Zn}$ with detection limits of $0.01,0.005$, $0.005,0.1,0.08,0.005 \mathrm{mg} / \mathrm{L}$.

Quality control was implemented through the use of precision analysis using 10 replicate samples, spiking was done using standards of concentration of each studied metal and reagent blank. Precision studies for the determination of heavy metals in water ranged $3-16 \%$ and recovery studies gave $79-104 \%$. Data provided were average of three replicate samples. The values of these parameters were compared to FEPA and WHO permissible guidelines for drinking water.

\section{Results and Discussion}

The summary of the concentration of metals in the water sample for the rainy and dry seasons and their mean are listed in Table 2. Generally, the metal levels were low and there were no significant differences in metallic levels in the samples collected upstream and downstream of the river. $\mathrm{Cd}$ concentration in the three locations ranged from $<0.01-0.06, \mathrm{Cu}$ ranged $<0.01$ 0.10 , Ni ranged $<0.01-0.01, \mathrm{~Pb}$ ranged $<0.01-0.01$ and Zn ranged 0.02- $0.04 \mathrm{mg} / \mathrm{L}$. Cd concentration was lowest in L4 and the same in L2 and L3. Cu concentration was highest in L4 and the same in L2 and L3. Zn concentration in L2 and L4 were the same and higher than L3. The concentrations of the heavy metals were higher during the RS than the DS. The lowest metal concentration levels were observed during the DS for $\mathrm{Cu}, \mathrm{Cd}, \mathrm{Ni}$ and $\mathrm{Pb}(<0.01 \mathrm{mg} / \mathrm{L})$. Significant seasonal variations were observed between DS and RS in the 


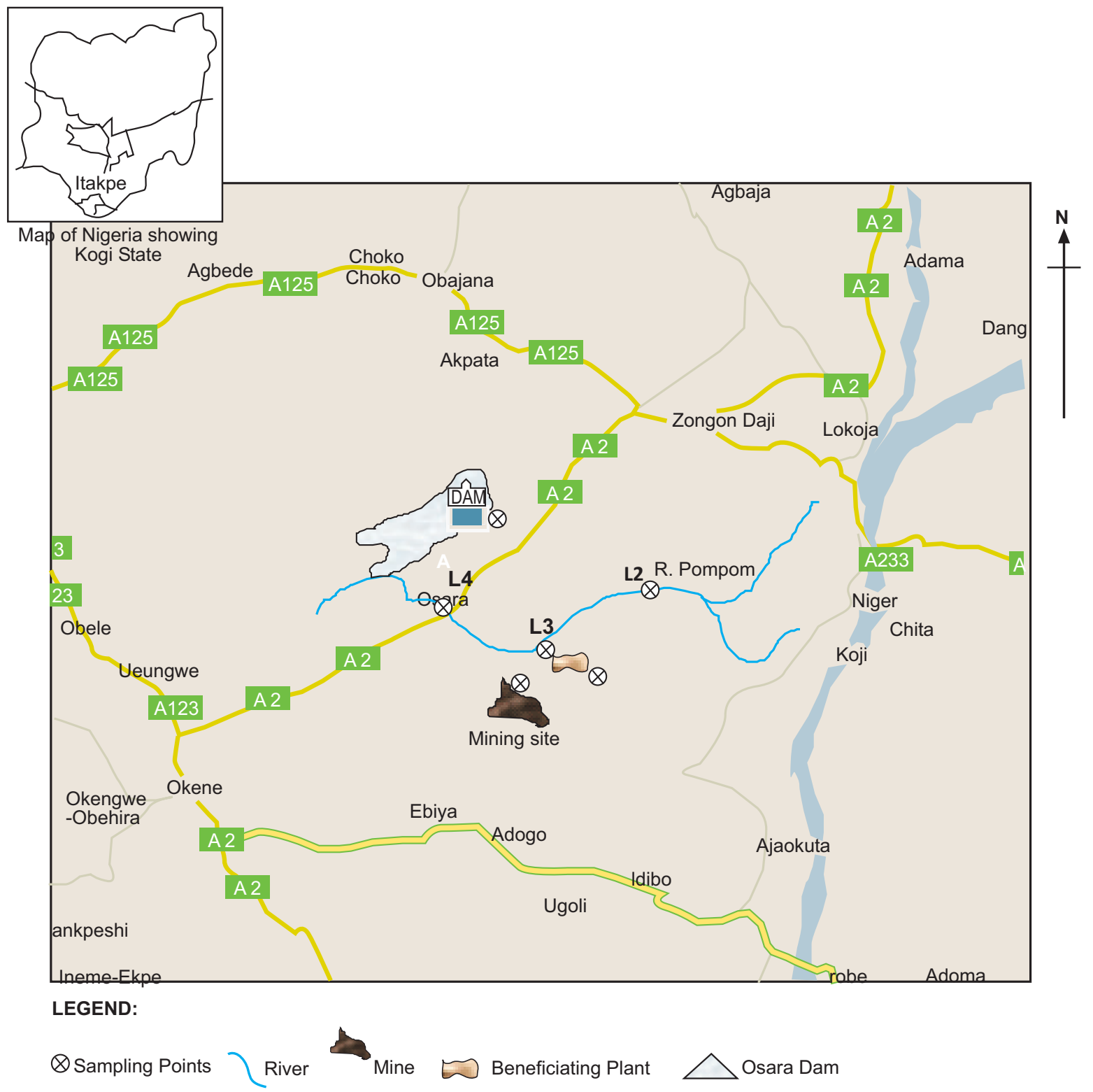

Fig. 1 Map of Itakpe mining environment showing sampling area.

Table 1. Sample descriptions and locations

\begin{tabular}{|c|c|c|c|}
\hline Sample & $\begin{array}{l}\text { Sample } \\
\text { description }\end{array}$ & Source & Bearing \\
\hline \multirow[t]{2}{*}{ L2 } & Water & Beneficiating & $7^{\circ} 37.187^{\prime} \mathrm{N}$ \\
\hline & & Plant area & $6^{\circ} 19.673^{\prime} \mathrm{E}$ \\
\hline \multirow[t]{2}{*}{ L3 } & Water & Beneficiating & $7^{\circ} 37.052^{\prime} \mathrm{N}$ \\
\hline & & Plant area & $6^{\circ} 19.173^{\prime} \mathrm{E}$ \\
\hline \multirow[t]{2}{*}{ L4 } & Water & Mining site area & $7^{\circ} 36.929^{\prime} \mathrm{N}$ \\
\hline & & & $6^{\circ} 18.626^{\prime} \mathrm{E}$ \\
\hline
\end{tabular}

concentrations of $\mathrm{Cd}, \mathrm{Cu}, \mathrm{Ni}$ and $\mathrm{Pb}$, whereas, in case of $\mathrm{Zn}$ the seasonal change was not significant. $\mathrm{Cu}$ level was highest during the RS followed by $\mathrm{Cd}$. $\mathrm{Ni}$ and $\mathrm{Pb}$ were the same concentration in all the locations during the RS.

Heavy metals in natural water are present in colloidal, particulate and dissolved forms with the proportion of these forms varying with metals and for different water bodies. Rivers are pathway for metal transport with dispersion patterns dependent on the solubility, mobility and species of each metal. According to Papafilippaki 
Table 2. Concentration $(\mu \mathrm{g} / \mathrm{L})$ of metals in the water samples in dry and rainy season

\begin{tabular}{|c|c|c|c|c|}
\hline Metal & Location & $\begin{array}{l}\text { Dry } \\
\text { season } \\
\text { (DS) }\end{array}$ & $\begin{array}{l}\text { Rainy } \\
\text { season } \\
\text { (RS) }\end{array}$ & $\begin{array}{l}\text { Mean } \\
\text { (RS\&DS) }\end{array}$ \\
\hline \multirow{3}{*}{$\mathrm{Cd}$} & $\mathrm{L} 2$ & $<0.01$ & $0.06 \pm 0.004$ & \\
\hline & L3 & $<0.01$ & $0.06 \pm 0.004$ & \\
\hline & L4 & $<0.01$ & $0.04 \pm 0.001$ & \\
\hline Mean & & $<0.01$ & $0.05 \pm 0.003$ & $0.03 \pm 0.003$ \\
\hline Range & & - & $0.047-0.053$ & $0.027-0.033$ \\
\hline \multirow[t]{3}{*}{$\mathrm{Cu}$} & $\mathrm{L} 2$ & $<0.01$ & $0.08 \pm 0.005$ & \\
\hline & L3 & $<0.01$ & $0.08 \pm 0.005$ & \\
\hline & L4 & $<0.01$ & $0.10 \pm 0.003$ & \\
\hline Mean & & $<0.01$ & $0.09 \pm 0.004$ & $0.05 \pm 0.002$ \\
\hline Range & & - & 0.086-0.094 & $0.048-0.052$ \\
\hline \multirow[t]{3}{*}{$\mathrm{Ni}$} & $\mathrm{L} 2$ & $<0.01$ & $0.01 \pm 0.001$ & \\
\hline & L3 & $<0.01$ & $0.01 \pm 0.001$ & \\
\hline & L4 & $<0.01$ & $0.01 \pm 0.004$ & \\
\hline Mean & & $<0.01$ & $0.01 \pm 0.002$ & $0.01 \pm 0.002$ \\
\hline Range & & - & $0.008-0.012$ & $0.008-0.012$ \\
\hline \multirow[t]{3}{*}{$\mathrm{Pb}$} & $\mathrm{L} 2$ & $<0.01$ & $0.01 \pm 0.001$ & \\
\hline & L3 & $<0.01$ & $0.01 \pm 0.001$ & \\
\hline & L4 & $<0.01$ & $0.01 \pm 0.001$ & \\
\hline Mean & & $<0.01$ & $0.01 \pm 0.001$ & $0.01 \pm 0.001$ \\
\hline Range & & - & $0.009-0.011$ & $0.009-0.011$ \\
\hline \multirow[t]{3}{*}{$\mathrm{Zn}$} & $\mathrm{L} 2$ & $0.03 \pm 0.001$ & $0.04 \pm 0.001$ & \\
\hline & L3 & $0.02 \pm 0.002$ & $0.03 \pm 0.002$ & \\
\hline & L4 & $0.03 \pm 0.001$ & $0.04 \pm 0.003$ & \\
\hline Mean & & $0.03 \pm 0.001$ & $0.04 \pm 0.002$ & $0.04 \pm 0.002$ \\
\hline Range & & $0.029-0.031$ & $0.038-0.042$ & $0.038-0.042$ \\
\hline
\end{tabular}

et al. (2008) metals undergo numerous changes in their speciation during transportation due to dissolution, precipitation, sorption and complexation phenomena which affect their behaviour and bioavailability. Their behaviour depends on the sediment, suspended particulate matter and water composition, while the $\mathrm{pH}$, redox, temperature and river flow control their solubility and speciation (Thorslund et al., 2012; Papafilippaki et al., 2008; Marcovecchio et al., 2007). Natural mass flow of heavy metals in dissolved form was reported by Thorslund et al. (2012) to increase by an order of magnitude due to mining. Gold mining at the Zaamar mine in Mongolia is reported to increase the total riverine mass flows of Al, As, $\mathrm{Cu}, \mathrm{Fe}, \mathrm{Mn}, \mathrm{Pb}$ and $\mathrm{Zn}$ by 44.300 , 30.1, 65.7, 47.800, 1.480, 76.0 and 65.0 tonnes/yr, respectively (Thorslund et al., 2012).
All the metals studied were present in the water sample. There was no specific distribution pattern with metallic concentration levels in the locations. This is due to the varieties of sources and the several factors which determine the release of these metals into the river. These sources may be attributed to industrial waste, weathering of rocks and minerals, soil leaching and the geochemical characteristics and mineralisation of the tailings. Nonpoint sources such as agricultural activity and atmospheric sources also introduce heavy metals into the river Pompom. Climate change could impact on the sources of these metallic pollutants. Other possible sources of heavy metals into the Pompom river could be due to the discharge of industrial effluents as a result of leakages from waste pipes and reagents added during mineral processing. $\mathrm{Hg}$ and $\mathrm{CN}$ have been reported to be part of the components of reagent used in mineral processing (Ato et al., 2010; Cordos et al., 2003). Inorganic Hg could be methylated in the water environment and lead to levels in fish and other high-level predators which pose a human health risk (Loredo et al., 2000). CN affects all components of the aquatic ecosystem: change in water quality, decrease in a number of fish species and some of the microalgae and mollusks species have been reported to disappear (Cordos et al., 2003).

The generally low metallic levels observed in the studied metals could be due to the distance of the mine from the river and the low level of contaminants entering the river Pompom as a result of the stoppage of mining. Sedimentation process could take place leading to the less soluble metal forms accumulating in suspended or sediment phase. Laws (2003) reported the transport of Cd downstream in suspended form, while Panutrakul et al. (2003) findings reported more than $70 \%$ of all the studied metals to be present in particulate form with Fe more than $95 \%$. Low concentration levels of some metals could be due to the speciation of metals which makes them readily absorbed by marine plants and organic matter resulting in their consequent settlement to the bottom of the river.

The higher metallic levels during the RS could be due to the introduction of lots of detritus and pollutants through erosion. Acid mine drainage (AMD) occurs as a result of the exposure of sulphide minerals present in heaps of tailings in the vicinity of the mines to water and oxygen. Series of chemical reaction results in water discharges high in acidity and concentration of metals. Furthermore, ferric ions produced by the oxidation of the pyrite minerals are capable of dissolving other heavy metal minerals (Makhoukh, 2011; Cordos et al., 2003; 
DeNicola and Stapleton, 2002). High acidity, increased concentration of heavy metals and precipitate of metals caused by AMD runoff into rivers results in reduction of benthic macroinvertebrate abundance and diversity (DeNicola and Stapleton, 2002). The high level of Cd and $\mathrm{Cu}$ during the $\mathrm{RS}$ could be due to impute from agrochemicals which results in the introduction of heavy metals into soil which is leached into the river. $\mathrm{Cd}$ and $\mathrm{Cu}$ have been reported to be components of fertilisers and pesticides (Traichaiyaporn and Chitmanat, 2008). $\mathrm{Cu}$ is a trace element essential to life, but, at high concentrations it can be toxic to humans (Nirel and Pasquini, 2010). Cadmium is very soluble in water and is one of the most toxic elements. At high concentrations $\mathrm{Cd}$ can lead to chronic kidney dysfunction, carcinogenic effects in humans, induction of cell injury and death by interfering with $\mathrm{Ca}$ regulation in biological systems in human. Studies by Traichaiyaporn and Chitmanat (2008) reports combustion of fossil fuels used in mining activities as leaking heavy metals such as $\mathrm{Pb}$ into the atmosphere. Exposure to $\mathrm{Pb}$ in drinking water above the permissible level can result in delays in physical and mental development, along with deficits in attention span and learning abilities in babies and children (Lawson, 2011).

Rainfall causes dissolution of gases such as carbon dioxide, oxygen, sulphur dioxide and nitrogen present in air through windblown dust, deforestation forest fires and volcanic particles. This results in toxic run off dissolving and picking up other substances causing an increase in metallic levels in the river during the RS (Lawson, 2011). Findings by other researchers have reported low metallic levels during the RS to be due to excessive rains which cause dilution in soil solution and results in the reduction of metal concentrations flowing into water bodies (Sankar et al., 2010; Palaniappan et al., 2010; Papafilippaki et al., 2008; Ezeronye and Ubalua, 2005).

The low metallic levels observed during the DS could be as a result of low flow of contaminants due to reduction in the volume of water. According to Makhoukh et al. (2011) during the DS due to low hydrodynamics particles are settled and heavy metals are trapped in sediments and organic matter. Some researchers have reported low levels during DS to be due to high temperatures in the water and alkalinity of water which leads to increase in concentration of sulphides due to their precipitation (metals are reported to precipitate along with the sulphides) (Papafilippaki et al., 2008; Salem et al., 2000). Papafilippaki et al.
(2008) and Cordos et al. (2003) reported high temperature during DS and its impact on the rates of metabolism, resulting in death of aquatic organisms with the release of metals. This is also reported that high levels during the DS could be due to sulphide oxidising bacterial activity increasing with temperature and concentrating the dissolved pollutants due to water evaporation (Papafilippaki et al., 2008).

Some other researchers have found no variation in metal levels during rainy and dry seasons (Dan'azumi and Bichi, 2010; Obasohan et al 2006; Ezeronye and Ubalua, 2005; Salem et al., 2000). According to Salem et al. (2000) this could be as a result of the influence of the nature of contaminants discharged into the river.

The distribution pattern of heavy metal in the Pompom river may have been affected by environmental conditions such as the release of heavy metals into surface waters from sediments, natural rocks and soils in the mining area. Deposition of large quantities of tailings into rivers results in alteration of instream substrata (Besser et al., 2007). A decreased redox potential in the river when there is deficiency of oxygen, changes composition of metal complexes releasing metal ions (Lawson, 2011). In soils containing high amounts of soluble substances, such as limestone the runoff will have high concentrations of calcium carbonate (Lawson, 2011). The presence of carbonate formations results in alkaline conditions which favours adsorption and complexation of metals, most of which become insoluble and precipitate causing restrictions in the transport of heavy metals (Kumanova et al., 2012; Thorslund et al., 2012; Makhoukh et al., 2011; DeNicola and Stapleton, 2002). Findings by DeNicola and Stapleton (2002) report the precipitation of dissolved metals such as $\mathrm{Al}, \mathrm{Zn}, \mathrm{Cu}$, and $\mathrm{Pb}$ when $\mathrm{AMD}$ runs into alkaline condition in streams. The physical layout and topography of the land can have an increased effect on the weathering and erosion rates of surrounding environment (Cordos et al., 2003). Mine tailings scoured by precipitation could converge into rivers with the topography as factor controlling the water flow paths. Thorslund et al. (2012) reported mining and ore excavation as causing acidification and heavy metal transport in the downstream water system.

There were no big differences in metallic concentration for samples collected upstream and downstream of the river. Water could become more polluted as it flows downstream due to increased imputes. However, there 
could be variations in metallic levels upstream and downstream due to several reasons such as the continuous, multiple, varying adsorption/desorption mechanisms depending on the transportation processes of suspended solids and dynamically changing discharges entering into the river. Heavy metals found in the suspended and colloidal phases could sediment at the upstream resulting in decrease in their bioavailability downstream. Physical and chemical conditions in the sediment and hydrology could affect the transport of metals from upstream mining areas resulting in high concentrations of dissolved heavy metals in downstream parts of the river (Thorslund et al., 2012; DeNicola and Stapleton, 2002). There could be distribution of heavy metals to tributaries as the river flows. According to Cordos et al. (2003) the physical and chemical characteristics of tributaries that flow into the river downstream may aid chemical reactions that increase or decrease the concentrations levels of heavy metals. Increase in atmospheric deposition could take place as the river flows down stream. The presence of a dam could cause secondary sources of pollution increasing the metallic concentration level downstream (Cordos et al., 2003).

$\mathrm{Cu}, \mathrm{Ni}, \mathrm{Pb}$ and $\mathrm{Zn}$ metallic levels of the studied metals were within values of FEPA and WHO permissible guidelines for drinking water.

\section{Conclusion}

Significant difference $(\mathrm{P}<0.05)$ were found between rainy and dry season in some of the studied metals $(\mathrm{Cd}, \mathrm{Pb}, \mathrm{Cu}$ and $\mathrm{Ni})$. The seasonal variations may be due to anthropogenic causes such as mining, agricultural practices, geochemical structure and industrial waste. $\mathrm{Cd}, \mathrm{Pb}, \mathrm{Cu}$ and $\mathrm{Ni}$ metallic levels of the studied metals were within levels of Federal Environmental Protection Agency (FEPA) of Nigeria and WHO permissible guidelines for drinking water. The accurate determinations of heavy metals in aquatic environment are of ultimate importance for controlling their pollution. There will be need to have a regular check of level of heavy metals in the water, sediments and soil samples in the Itakpe mining environment to assess environmental impact to avoid pollutants eventually becoming potential health risk to residents in the vicinity of the mining area.

\section{References}

Abolude, D.S., Davies, O.A., Chia, A.M. 2009. Distribution and concentration of trace elements in Kubanni reservoir in Northern Nigeria. Research Journal of Environmental and Earth Sciences, 1: 39-44.

Ato, A.F., Samuel, O., Oscar, Y.D., Moi, P.A.N., Akoto, B. 2010. Mining and heavy metal pollution: assessment of aquatic environments in Tarkwa (Ghana) using multivariate statistical analysis. Journal of Environmental Statistics, 1: 1-13.

Besser, J.M., Finger, S.E., Church, S.E. 2007. Impacts of historical mining on aquatic ecosystems; An ecological risk assessment. In: Chapter $D$ of Integrated Investigations of Environmental Effects of Historical Mining in the Animas River Watershed, San Juan County, Colorado, S.E. Church, P. Vong Guerard and S. E. Finger (eds.), Professional Paper 1651, pp. 87-106, Publisher: U.S. Geological Survey.

Cordos, E., Rautiu,R., Roman, C., Ponta, M., Frentiu, T., Sarkany, A., Fodorpataki, L., Macalik, K., Mc Cormick, C., Weiss, D. 2003. Characterization of the rivers system in the mining and industrial area of Baia Mare, Romania. The European Journal of Mineral Processing and Environmental Protection, 3: 324-335.

Dan'azumi, S., Bichi, M.H. 2010. Industrial pollution and heavy metals profile of Challawa river in Kano, Nigeria. Journal of Applied Science in Environmental Sanitation, 5: 56-62.

De Nicola, D.M., Stapleton, M.G. 2002. Impact of acid mine drainage on benthic communities in streams: the relative roles of substratum $v s$. aqueous effects. Environmental Pollution, 119: 303-315.

Ezeronye, O.U., Ubalua, A.O. 2005. Studies on the effect of abattoir and industrial effluents on the heavy metals and microbial quality of Aba river in Nigeria. African Journal of Biotechnology, 4: 266-272.

Kumanova, X., Leka, G., Jacks, G. 2012. Heavy metal transport in the river Fani and river Mati, Albania. BALWOIS 2012-Ohrid, Republic of Macedonia28 May - 2 June 2012, pp. 1-5.

Laws, E.A. 2000. Metals. In: Aquatic Pollution - An Introductory Text, E.R. Laws and G.B. Udvarhelyi (eds.), pp. 369-431, $3^{\text {rd }}$ edition, John Wiley and Sons, New York, USA.

Lawson, O.E. 2011. Physicochemical parameters and heavy metal contents of water from the mangrove swamps of Lagos lagoon, Lagos, Nigeria. Advances in Biological Research, 5: 8-21.

Loredo, J., Ordonez, A., Galán, M.P., Fernández-Martínez, R., Alvarez, R., Olay, A., Petit-Domínguez, M., Fernández, R.M., Marín, S., González M.M., 
Rucandio, M.I. 2005. Surface water monitoring in abandoned mercury mine sites in Asturias (Spain): Comparitive studies. In: Proceeding of $9^{\text {th }}$ International Mine Water Congress, J. Loredo and F. Peridas (eds.), pp. 595-601, Oviedo University, Oviedo, Spain. Makhoukh, M., Sbaa, M., Berrahou, A., Vanclooster, M. 2011. Assessing water and sediment quality of the Moulouya river (east-Morocco). European Journal of Scientific Research, 61: 508-523.

Marcovecchio, J.E., Botte, S.E., Freije, R.H. 2007. Heavy metal, major metals, trace metals. In: Handbook of Water Analysis, L. M. Nollet (ed.), pp. 275-311, $2^{\text {nd }}$ edition, CRC Press, London, UK.

Nirel, P.M., Pasquini, F. 2010. Differentiation of copper pollution origin: agricultural and urban sources. Novatech, 1-7.

Obasohan, E,E., Oronsaye, J.A.O., Obano, E.E. 2006. Heavy metal concentrations in Malapterurus Electicus and chryscichthys nigrodigitatus from Ogba river in Benin city, Nigeria. African Journal of Biotechnology, 5: 974-982.

Palaniappan, M., Gleick, P.H., Allen, L., Cohen, M.J., Christian-Smith, M.J., Smith, C. 2010. Clearing the Waters: A Focus on Water Quality Solutions, Report Prepared for the United Nations Environment Programme (UNEP), Pasific Institute.

Panutrakul, S., Musica, C., Mokkongpai, P. 2003. Behaviour of some Heavy Metals in the Bangpakong River Estuary. In: Environment 2010: Situation and
Perspectives for the European Union, Proceedings of the International Symposium, University of Porto, Portugal.

Papafilippaki, A.K., Kotti, M.E., Stavroulakis, G.G. 2008. Seasonal variations in dissolved heavy metals the Keritis river, Chania, Greece. Global NEST Journal, 10: 320-325.

Salem, M.H., Eweidia, E.A., Farag, A. 2000. Heavy metals in drinking water and their environmental impact on human health. Proceedings of the International Conference for the Environmental Hazard Mitigatin, Cairo University, pp. 542-556.

Sankar, R.L., Ramkumar, R., Sun, J., Ananthan, G. 2010. Seasonal variations in physicochemical parameters and heavy metals in water and sediments of Uppanar estuary, Nagapattinam, India. Journal of Environmental Biology, 31: 681-686.

Thorslund, J., Jarsjö, J., Chalov, S.R., Belozerova, E. 2012. Gold mining impact on riverine heavy metal transport in a sparsely monitored region: the upper Lake Baikal Basin case. Journal of Environmental Monitoring, 14: 2780-2792.

Traichaiyaporn, S., Chitmanat, C. 2008. Water quality monitoring in upper Ping river, Thailand. Journal of Agriculture and Social Sciences, 4: 31-34.

USEPA, 2008. US Environment Protection Agency, Sample pretreatment by digestion. In: Water Analysis Handbook, pp. 49-50, $5^{\text {th }}$ edition, $\mathrm{HACH}$ Company, Loveland, Colorado, USA. 